\title{
Altered Nuclear Functions in Progeroid Syndromes: a Paradigm for Aging Research
}

\author{
Baomin $\mathrm{Li}^{1}$, Sonali $\mathrm{Jog}^{1}$, Jose Candelario ${ }^{1}$, Sita Reddy ${ }^{2}$, and Lucio Comai ${ }^{1, *}$ \\ ${ }^{1}$ Department of Molecular Microbiology and Immunology, ${ }^{2}$ Department of Biochemistry \\ and Molecular Biology, Institute for Genetic Medicine, Keck School of Medicine, \\ University of Southern California, Los Angeles \\ E-mail: $\underline{\text { comai@usc.edu }}$
}

Received August 5, 2009; Revised November 23, 2009; Accepted November 24, 2009; Published December 16, 2009

Syndromes of accelerated aging could provide an entry point for identifying and dissecting the cellular pathways that are involved in the development of age-related pathologies in the general population. However, their usefulness for aging research has been controversial, as it has been argued that these diseases do not faithfully reflect the process of natural aging. Here we review recent findings on the molecular basis of two progeroid diseases, Werner syndrome (WS) and Hutchinson-Gilford progeria syndrome (HGPS), and highlight functional connections to cellular processes that may contribute to normal aging.

KEYWORDS: aging, Werner syndrome, Hutchinson-Gilford progeria syndrome, lamin, telomere

\section{INTRODUCTION}

As the average life span of the human population is steadily rising, at least in the western world, the increased incidence of a wide range of diseases with age has become a critical human health issue and an important topic in biomedical research. The identification and biochemical characterization of the molecular alterations that occur during the aging process can provide critical insights into the cellular events that predispose us to the development of age-related diseases. Progeroid syndromes, which are rare disorders that shorten life expectancy, represent a valuable model for studying the aging process, as patients with these diseases display early onset of many, although not necessarily all, features of normal aging. The identification, in the last decade, of the genetic mutations responsible for two progeroid diseases, Werner syndrome (WS) and Hutchinson-Gilford progeria syndrome (HGPS), has permitted molecular studies aimed at dissecting the underlying causes of these diseases and their possible relationship with the process of natural aging. These studies, which have provided a number of critical information at the molecular and cellular levels on specific nuclear functions that, when altered, cause WS and HGPS, could perhaps provide valuable information for understanding the molecular basis of ageassociated pathologies in the general population. 


\section{THE MOLECULAR BASIS OF WERNER SYNDROME}

\section{Werner Syndrome Protein is a RecQ Helicase with a Unique Exonuclease Activity}

WS is an autosomal-recessive, premature aging disorder[1,2] that is typically diagnosed in individuals 20-30 years of age. WS patients display a striking predisposition to an early onset of several diseases that are generally observed during normal aging, such as cataracts, arteriosclerosis, osteoporosis, type II diabetes mellitus, and a variety of tumors, primarily of mesenchymal origin. Myocardial infarction and cancer are the most common causes of death among WS patients, with a median age of death of approximately 47 years[1,3]. WS is caused by mutations in a single gene located on chromosome 8[4]. The gene encodes a protein, termed Werner syndrome protein (WRN), which belongs to a class of enzymes known as RecQ helicases[4,5].

WRN helicases can unwind a number of different DNA structures, from linear duplex DNA to a 5' single-strand region of flap DNA substrates, synthetic replication forks, and Holliday junctions[6,7]. In addition, WRN as well as Bloom syndrome protein (BLM), a related human RecQ helicase, can efficiently unwind G-rich DNA substrates that have the tendency to form structures known as G quadruplexes, which cons ist of four arrangements of guanine stabilized by Hoogsteen hydrogen bonding and monovalent cations[6]. G-rich sequences are widely distributed within the human genome and are found at the promoter region of several proto-oncogenes, at immunoglobulin switch regions, ribosomal DNA gene locus, and telomeric repeat regions[8]. WRN is unique among the members of the RecQ family of helicases in that it possesses a 3 ' to 5'exonuclease activity that is highly homologous to the nuclease domain of E. coli DNA polymerase I and ribonuclease D (RNase D)[9]. Since the helicase properties of WRN are similar to those of BLM, it is likely that the characterization of the exonuclease activity and identification of its bona fide substrates will provide mechanistic insights on the specific cellular function of the WRN protein.

All the WRN mutations that have been identified to date in WS patients are nonsense or frameshift mutations leading to the synthesis of a truncated protein lacking the nuclear localization signal, which is located at the carboxyl-terminal end of WRN. As most cell lines from WS patients show no detectable WRN protein[10], the prevailing hypothesis is that the truncated protein fails to enter the nucleus and is rapidly degraded, thus resulting in complete loss of WRN function. At the cellular level, cultured primary fibroblasts from WS patients have a decreased replicative life span compared to fibroblasts from healthy individuals, and display chromosomal translocation and deletions[11,12,13], suggesting that lack of WS function causes genome instability. In an effort to create animal models of the disease, several groups have generated mice with WRN mutations. Mice bearing a deletion of the helicase domain or a point mutation that eliminates WRN expression do not show signs of premature aging, genomic instability, or increased sensitivity to genotoxins[14,15]. In contrast, several of the phenotypes observed in WS patients are recapitulated in late-generation mice lacking both WRN and telomerase activities[16,17], suggesting that defects in telomere length homeostasis may contribute to the pathology of the disease, at least in mice.

\section{WRN in the Metabolism of DNA Ends}

To gain insights into the physiological function of WRN, our lab and others have pursued studies aimed at identifying molecular partners of WRN and characterizing their functional relationship. These studies have revealed binary interactions between WRN and several nuclear proteins, including Ku70/80, BLM, FEN1, TRF2, p53, po1 $\beta$, pol $\delta$, RAD51, RAD52, RAD54B, RPA, POT1, PCNA, PARP1, MRE11, and Cdc5L[18,19,20,21,22,23,24,25,26,27,28,29,30,31,32]. As these proteins are involved in a variety of nuclear processes, including DNA replication, repair, recombination, and telomere metabolism, these findings suggest that WRN might function in any of these DNA transactions. Among this plethora of interacting proteins, the physical and functional interaction between WRN and the Ku heterodimer has been the focus of several investigative studies since it is likely to play a key role in processes required for 
maintaining genome stability[18,19,33,34,35,36,37]. Indeed, Ku70/80 is a heterodimer $(\mathrm{Ku})$ that binds DNA ends and functions in the repair of DNA double-strand breaks (DSBs) by nonhomologous DNA end joining (NHEJ)[38]. In addition, Ku has recently been implicated in the maintenance of telomeres through as-yet-incompletely-defined mechanis ms[39]. Hence, it is likely that the interaction between WRN and $\mathrm{Ku}$ influences processes occurring at both pathological (DNA breaks) and natural (te lomeres) DNA ends (Fig. 1). A subpopulation of $\mathrm{Ku}$ forms a stable functional complex with WRN in human cells and is responsible for the recruitment of WRN to DNA ends and for altering the properties of WRN exonuclease activity on a variety of DNA substrates in vitro[18,28,35,36,37]. In support of the concept that the interaction between WRN and Ku plays an important role in cell function, genetic studies demonstrated that cells from Ku80-null mice display similarities to human WS fibroblasts, including a high degree of genomic instability characterized by chromosome translocations and rearrangements[40,41,42]. Significantly, both Ku70 and Ku80 knockout mice display characteristics of premature aging[41,43]. Thus, biochemical and genetic evidence strongly suggest that Ku and WRN participate in a common, but yet to be defined, cellular pathway, possibly linked to the metabolism of DNA ends, which regulates cellular and organismal aging.

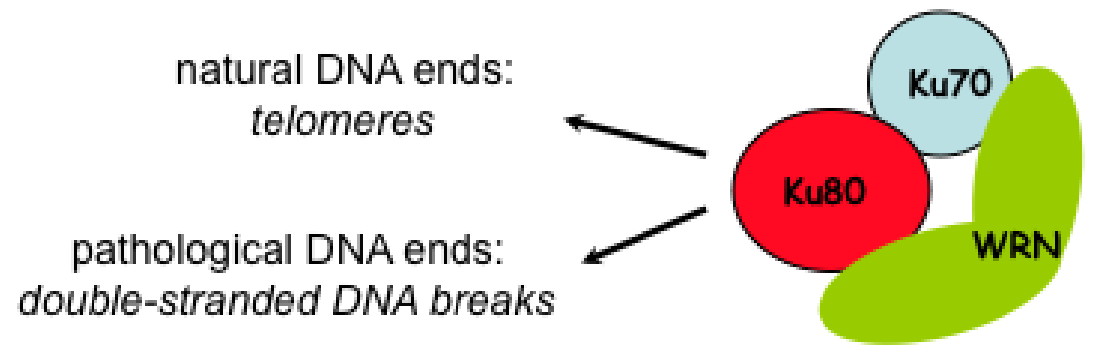

FIGURE 1. The identification of a strong interaction between WRN and the Ku70/80 het erodimer suggests a role for WRN in the met abolism of DNA ends.

\section{Abnormal Telomere Homeostasis is an Important Molecular Event in WS Pathology}

Recent studies have demonstrated that a subpopulation of WRN localizes at telomeres (Fig. 2; [44,45]) and interacts with at least two telomere-associated proteins, TRF2 and POT1[26,27,46]. In vitro studies have further indicated that POT1 stimulates WRN helicase[27] and limits WRN exonuclease processivity on telomeric substrates with 3' overhangs[47]. In addition, the telomere repeat binding factor TRF2 has been shown to regulate both WRN enzymatic activities, although the specific effect that TRF2 exerts on WRN exonuclease has not been conclusively established[45,46]. Critical evidence supporting a functional role for WRN at telomere comes from cell-based studies, which demonstrated that lack of WRN leads to sporadic loss of telomeric DNA generated by lagging DNA synthesis (sister telomere loss or STL), a process that can be prevented by expression of either a fully functional or exonuclease-deficient WRN, but not by a WRN mutant lacking helicase activity[44]. This finding suggests that helicase, but not exonuclease, activity is important for preventing STL. Other studies have further indicated that WRN may play a role in the preservation of telomeres in cells that maintain telomere length by a telomeraseindependent, recombination-based mechanism termed "Alternative Lengthening of Telomere" (ALT)[45,48]. Collectively, these studies point to telomeres as at least one important bona fide substrate of WRN and suggest that telomere dysfunction contributes to the pathology of WS.

Human telomeres are composed of several kilobases of the repetitive hexamer TTAGGG and contain a 3' single-stranded DNA extension that is thought to invade the complementary strand and establish the protective terminal structure termed telomeric-loop (T-loop) (Fig. 3)[49,50,51]. Disruption of the T-loop activates a DNA damage-response pathway and leads to cell cycle arrest, cell senescence, or apoptosis[52,53,54,55]. 


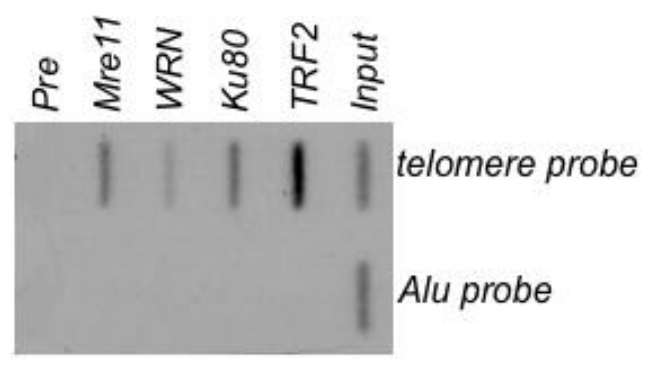

\section{Dot Blot}

FIGURE 2. Chromatin immunoprecipitation assays demonstrate the association of WRN with telomeres. Human fibroblasts were fixed with formaldehyde to stabilize protein-DNA complexes. The chromat in was then mechanically sheared to generate small DNA fragments. These fragments were immunoprecipitated with antibodies specific to the indicated proteins (pre $=$ preimmune serum). Following immunoprecipitation, the cross-link was reversed, DNA was isolated and analyzed by slot blot hybridization using either telomeric or Alu repeat s probes.

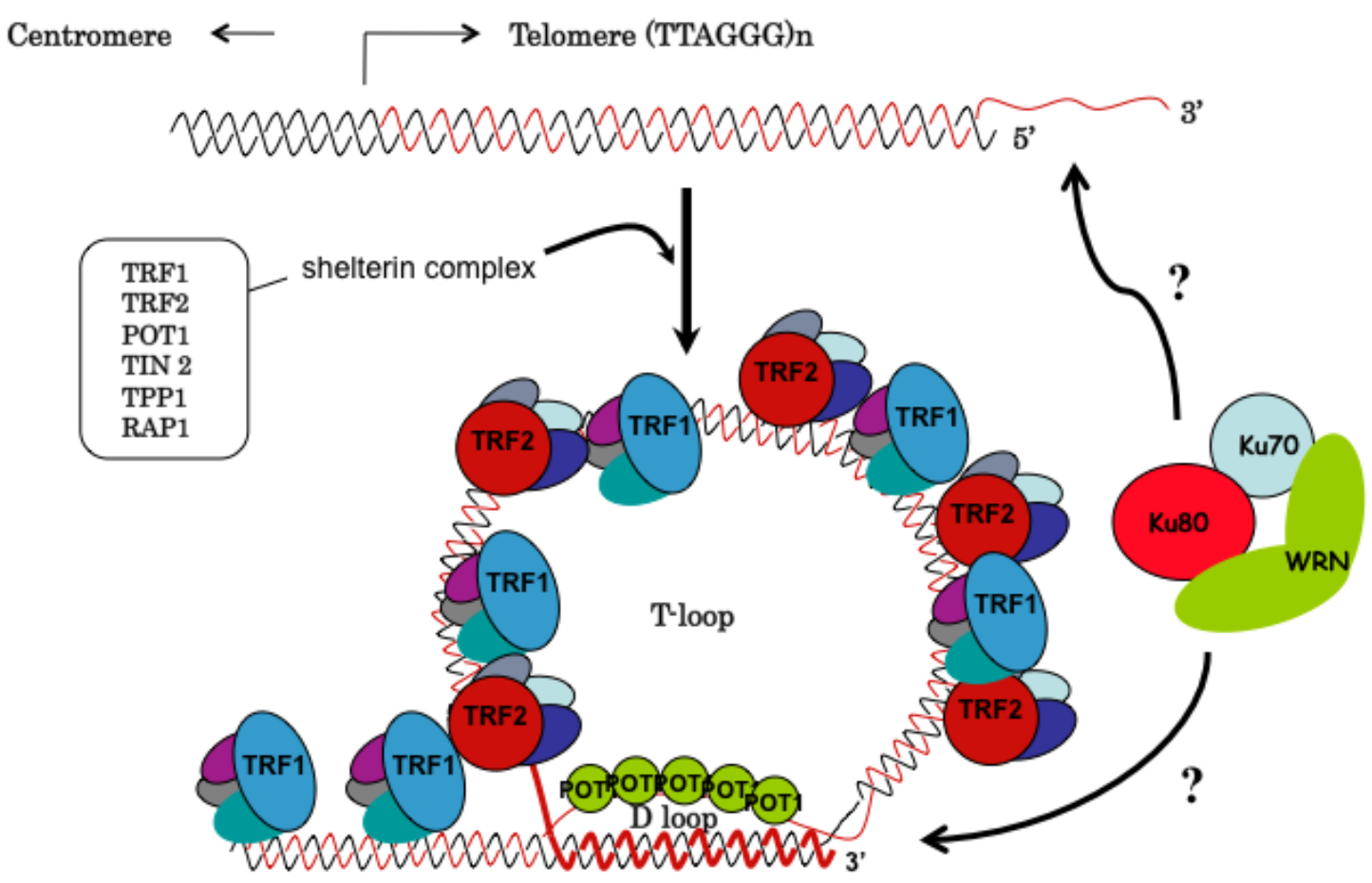

FIGURE 3. Hypothetical model of telomere end protection. The shelterin complex is required for the formation of the protective T-loop and plays a critical role in preventing telomere dysfunction leading to apoptosis or senescence. The mechanism by which the WRN complex influences the metabolism of chromosome ends is poorly understood.

The formation and maintenance of the T-loop is mediated by a multiprotein complex termed shelterin, which includes telomeric DNA-binding proteins, such as telomere repeat factor 1 and 2 (TRF1 and TRF2), the single-stranded telomeric DNA-binding protein POT1, and TIN2, TPP1, and RAP1, three factors that do not bind to te lomeric DNA directly (Fig. 3)[56]. The shelterin complex is implicated in the 
control of telomere length and protects telomere termini from end-to-end fusion and recombination[56]. Alterations that disturb the stoichiometry or composition of this complex can lead to dysfunctional telomere, and profoundly affect cell function and survival. Indeed, overexpression of a mutant TRF2 lacking the amino terminal basic domain $\left(\mathrm{TRF}^{\mathrm{AB}}\right.$ ) causes abrupt telomere deletions, formation of extrachromosomal telomere circles, and cellular senescence[57]. Significantly, WRN is required for $\mathrm{TRF}_{2}{ }^{\mathrm{B}}$-mediated te lomere shortening and cell senescence [58], suggesting a functional interplay between WRN and shelterin in the maintenance of the proper telomeric structure. Unexpectedly, elevated levels of t-circles are also observed in telomerase-positive WS cells and their level is not enhanced by expression of $\mathrm{TRF} 2^{\triangle \mathrm{B}}$, suggesting that loss of WRN function per se can induce the production of these aberrant telomere structures[58]. Helicase and exonuclease activities are required to suppress the formation of tcircles in cells expressing telomerase, suggesting that both activities play an important role in regulating telomere topology.

Extrachromosomal DNA circles composed of telomeric or nontelomeric sequences have been detected in cancer cells and during aging of mammalian cells[59,60,61]. Moreover, an increase in extrachromosomal ribosomal DNA (rDNA) circles has been reported as a hallmark of replicative aging in yeast[62]. Although the contribution of telomeric DNA circles to the development of cancer or to the aging process in mammals is unknown, these extrachromosomal DNA structures can potentially be a source of genome instability. For example, t-circles could integrate into intrachromosomal loci, thus generating internal telomeric repeats that are genetically unstable. The presence of extrachromosomal telomeric repeats could also have an indirect effect on telomere function by sequestering telomerebinding proteins away from their chromosomal binding sites, thus leaving telomeres in danger of nucleolytic attack. It is also possible that t-circles could be utilized as templates for telomeraseindependent telomere elongation, thus contributing to telomere length maintenance. Indeed, t-circles have been detected in human cancer cells that maintain telomere length through the telomerase-independent process ALT, and the formation of t-circles in ALT cells, as wells as cells expressing TRF2 ${ }^{\triangle \mathrm{B}}$, requires the presence of the recombination factors XRCC3 and NBS1[57,63]. In contrast to ALT cells, downregulation of XRCC3 does not reduce t-circle formation in WS cells, suggesting that alternative mechanisms of t-circle formation operate in these cells[58]. Notably, t-circles have also been observed in cells from Pot1 knockout mice, supporting the concept that alterations in telomere termini protection can lead to the formation of these extrachromosomal DNA structures[64]. Whether t-circles are simply byproducts of aberrant telomere metabolism or directly contribute to the maintenance of telomere length in any of these settings is currently unclear.

Remarkably, the WRN-interacting partner Ku70/80 has also been detected at telomeres and implicated in the regulation of telomere maintenance in a range of organisms including yeast, plants, mice, and humans[39]. Ku has been proposed to function both in the protection of telomere ends from degradation and in the regulation of telomere length, possibly through a functional interaction with the telomerase holoenzyme[65,66,67]. Yet, how Ku operates at telomeres seems to differ among species as, for example, cells from $\mathrm{Ku}$ knockout plants show extreme telomere elongation, while yeast lacking $\mathrm{Ku}$ display loss of telomere repeats[68,69]. While the basis for this divergence in function is unknown, it is likely to reflect natural species-specific variations in telomere biology. Interestingly, a recent study has demonstrated that inactivation of $\mathrm{Ku}$, which functionally interacts with WRN-like activities both in human and plants[18,70], induces the formation of t-circles in Arabidopsis[71]. Importantly, t-circle formation in Ku-deficient plants is not suppressed by inactivation of several genes involved in the homologous recombination pathway, including XRCC3[71]. Although this phenotype is reminiscent of that observed in WS fibroblasts, it remains to be determined whether Ku plays any role in the repression of t-circles in human cells (see note below) ${ }^{*}$.

\footnotetext{
* A recent study has shown that $\mathrm{Ku}$ is required to repress the formation of $\mathrm{t}$-circles in telomerase-positive human cells[123].
} 


\section{THE MOLECULAR BASIS OF HUTCHINSON GILFORD PROGERIA SYNDROME}

\section{Alterations in Prelamin A Processing Result in a Cellu lar Progeroid Phenotype}

HGPS is a rare, but devastating, autosomal-dominant genetic disorder observed in about 1 in 4 million children worldwide, which is associated with an early onset of several pathological features typical of premature aging[72,73]. The disease is characterized by severe growth retardation, micrognathia, abnormal dentition, osteoporos is and bone hypoplasia, gonadal defects, lipodystrophy, atherosclerosis, type 2 diabetes, and ske letal muscle atrophy[74]. Children with HGPS typically die due to cardiac failure between the ages of 13 and 16 years. It was not until 2003 that the long-sought genetic mutation responsible for the devastating disease HGPS was found to be located within the gene coding for lamin $\mathrm{A}[75,76]$. Lamin $\mathrm{A}$ is a nuclear protein and a member of the family of intermediate filaments. It is synthesized as a precursor molecule (prelamin A), which is then sequentially processed into the mature lamin A protein (Fig. 4). Processing involves a transient farnesylation and carboxymethylation of the carboxyl-terminal tail, which is ultimately cleaved off by the zinc metalloprotease ZMPSTE24. The processing time in normal human cells has been determined to take approximate ly $3 \mathrm{~h}[77,78]$.

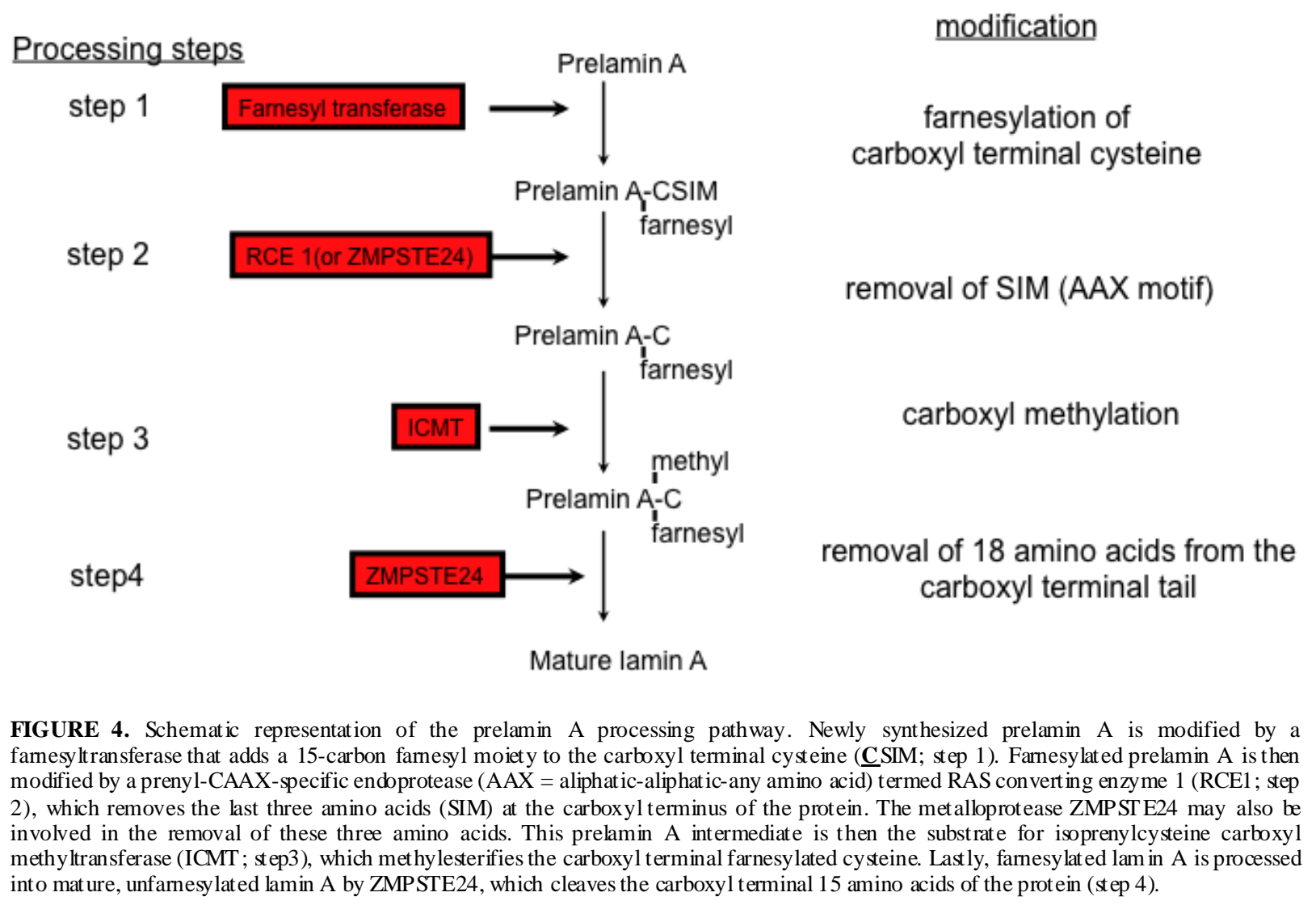

The most common mutation in HGPS patients is a de novo heterozygous $\mathrm{C}$ to $\mathrm{T}$ transition at nucleotide 1824 of the $L M N A$ gene, which results in the production of a cryptic splice site within exon 11[75,76]. Translation of the misspliced mRNA produces a mutant lamin A protein with an internal deletion of 50 amino acids, which lacks the internal proteolytic cleavage site necessary to remove the farnesylated carboxyl-terminal tail to generate mature lamin A[75,76]. The genetics of HGPS suggest that the mutant lamin A prote in, termed progerin, acts as in a dominant-negative fashion. Progeria cells and 
normal fibroblasts or Hela cells expressing ectopic progerin display severe growth defects and altered nuclear membrane morphology, and inhibition of prelamin A prenylation by treatment with farnesyltransferase inhibitors (FTIs) reverses, in part, the growth properties and the nuclear morphology defects of these cells $[79,80,81,82,83]$.

Striking evidence on the critical role that lamin A plays, not only in the pathology of progeria, but more generally in human health, comes from a relatively large number of studies that have demonstrated that specific point mutations in the LMNA gene cause a range of human disorders that affect distinct tissues or organs and are collectively known as laminopathies[84,85,86]. These include Emery-Dreifuss muscular dystrophy (EDMD2/3), Limb-Girdle muscular dystrophy (LGMD1B), dilated cardiomyopathy (conduction-system disease, CMD1A), familial autosomal-dominant partial lipodystrophy (Dunnigan variety, FPLD), autosomal-recessive Charcot-Marie-Tooth disease (DMT2B1), mandibuloacral dysplasia (MAD), and atypical WS. As the molecular basis of these diseases remains to be defined, it is anticipated that a detailed analysis of the cellular function of lamin A will provide key mechanistic insights on the causes of certain tissue-specific diseases.

\section{Lamin A is an Organizer of Chromatin Structure and Regulator of Gene Expression and DNA Replication}

The mechanisms by which mutations in lamin A alter nuclear function and cause disease are unclear. Lamin A is a component of the nuclear lamina, which is located in the inner side of the nuclear membrane and is believed to provide a mechanical framework for the support of the nuclear envelope[87,88]. In addition to this structural role, lamin A has been proposed to play an important function in the regulation of nuclear processes, since it interacts with chromatin, either directly or through association with other proteins $[87,89,90]$, and binds to at least three transcription factors: the serum responsive element binding protein (SREBP1), the retinoblastoma transcription factor (RB), and activating protein 1 (AP1) [91,92,93]. These findings suggest that lamin A may be involved in the organization of chromatin structure and regulation of gene expression, and one or both of these functions may be affected by the presence of mutant lamin A, including progerin. Indeed, accumulation of progerin causes relocalization or decreased levels of markers of heterochromatin, including heterochromatin prote in $1 \alpha$ (HP1 $1 \alpha$ ), histone H3 trimethylated on lysine 9 (H3K9-3me), and histone $\mathrm{H} 3$ trimethylated on lysine 27 (H3K27-3me), loss of heterochromatin associated with the inactive $\mathrm{X}$ chromosome, and activation of genes located in the normally silenced pericentric regions of the chromosomes[94,95,96,97,98]. Significantly, treatment with farnesyltransferase inhibitors, a condition that ameliorates the cellular phenotype, increases the pattern of histone H3K9-3me in HGPS cells[97]. Evidence for a direct involvement of lamin A in regulation of gene expression comes from studies showing that expression of a dominant-negative lamin A mutant lacking the NH2-terminal domain inhibits RNA polymerase II activity in both mammalian cells and isolated nuclei from Xenopus laevis[99]. Significantly, the gene expression profile of progeria cells closely resembles that of fibroblasts from old-age individuals[100], and comparison of the transcriptome between HGPS and control fibroblasts led to the identification a large number of genes that are expressed differentially in HGPS cells[101]. Moreover, the analysis of genes whose expression is altered soon after ectopic expression of progerin has indicated that aberrant activation of several genes involved in Notch signaling pathway may be implicated in the pathogenesis of progeria[102].

The interaction between lamin A and chromatin may also play a regulatory role in DNA synthesis. Indeed, lamin A has been shown to localize with sites of DNA replication and directly interacts with proliferating cell nuclear antigen (PCNA)[103,104]. Moreover, studies in cultured cells expressing a mutant form of lamin A lacking the amino terminal domain demonstrated abnormal distribution of two elongation factors, proliferating cell nuclear antigen (PCNA) and replication factor complex (RFC), and altered elongation phase of DNA replication[99,105]. Alterations in DNA replication have not been reported in progeria cells yet. However, it could be surmised that defective DNA replication leading to the collapse of replication forks may be at the basis of the increased levels of damaged DNA observed in 
progeria cells[106]. Thus it will be important to determine whether a fundamental nuclear process such as DNA replication is adversely affected by expression of progerin.

\section{The Lamin A Pathway in Cellular and Organismal Aging}

Although the relationship between HGPS and natural aging remains unclear, the recent identification of small amounts or progerin produced by sporadic usage of the cryptic slice site in cultured cells and skin biopsies from healthy individuals has raised the prospect that age-dependent accumulation of this mutant lamin A protein may be implicated in cell senescence and general human aging[107,108,109]. Significantly, the treatment of fibroblasts from old individuals with reagents designed to specifically reduce expression of the progerin-coding mRNA results in the reversal of age-associated nuclear defects, suggesting a direct causal relationship between the levels of this lamin A variant and these phenotypes[108]. A potential functional link between the lamin A pathway and cellular aging is further underscored by studies that demonstrated that in the absence of disease-causing mutations, alterations in the normal lamin A metabolism triggered by increased expression of wild-type prelamin A negatively influence cell function[83,110]. Notably, a mild increase in the expression of wild-type prelamin A in normal fibroblasts is sufficient to induce, albeit with slower kinetics, the set of alterations observed in progeria cells, including growth defects, nuclear membrane abnormalities, cell death, and premature senescence [83]. These alterations are reversed by overexpression of ZMPSTE24, indicating that abnormal processing of wild-type prelamin A is responsible for these phenotypic changes. An implication of this finding is that possible age-associated decreases in the activity of ZMPSTE24 could have a major impact on the processing of prelamin A and ultimately accelerate the aging process.

Expression of progerin induces aberrant, nonuniform thickening of the nuclear lamina and a reduced extractability of lamin A from nuclei, indicating a redistribution and aggregation of lamin A from the nucleoplasm to the nuclear membrane[96]. Signif icantly, the aberrant pattern of lamin A localization seen in progeria cells is also observed in cells expressing elevated levels of wild-type lamin A, in cells from old-age individuals, and in senescent cells, but rarely observed in cells from young individuals[83,111]. Whether these changes in lamin A localization are causally involved in cellular aging remains to be determined.

The role of lamin A in eliciting age-associated pathologies at the organismal level has been investigated by generating transgenic and knockout mouse models. Lmna knockout mice are normal at birth, but quickly develop a muscle phenotype that resembles Emery-Dreifuss muscular dystrophy[112]. Mice with a targeted mutation that unexpectedly alters Lmna splicing develop progeroid features, including loss of subcutaneous fat, decreased bone density, heart pathology, and muscle atrophy[113]. Two murine models of HGPS have been generated by the use of either a BAC clone containing the human mutation or by replacement of a 3' region of Lmna gene with a single exon that encodes the carboxyl terminus of progerin[114,115]. The BAC transgenic mice show a mild phenotype, which is restricted to the smooth muscle cells of the vascular system, while the second mice model displays several progeria-like phenotypes, including severe growth retardation, abnormal dentition, kyphosis, and fragile bones. However, the second mice model does not demonstrate vascular defects, cardiomyopathy, gonadal defects, muscle atrophy, and weakness, which also characterize progeria patients. Intriguingly, eliminating the synthesis of mature lamin A reduces disease phenotypes in mice carrying an HGPS allele[116], possibly suggesting a detrimental interplay between the normal and the mutant lamin A. It is currently unclear why the entire spectrum of defects observed in HGPS patients is not observed in either mouse model. Significantly, the relevance of the lamin A processing pathway in the development of ageassociated pathologies has been underscored by the demonstration that mutations in the ZMPSTE24 gene, both in humans and mice, lead to progeria-like syndromes characterized by growth retardation, skeletal abnormalities, and cutaneous atrophy[117,118,119]. 


\section{CONCLUDING REMARKS}

The identification of the mutations responsible for the premature aging diseases WS and HGPS has prompted intense investigations on the molecular basis of these diseases and their potential relationship to normal aging. These studies have shown that both mutations affect the function of prote ins that participate in nuclear processes required for maintaining proper cell function. Although at first sight the pathways affected by these progeroid diseases appear unrelated, a potentially interesting link is emerging, as recent studies have revealed that altered telomere homeostasis is observed not only in WS as a pathological phenotype, but also in progeria cells and cells ectopically expressing progerin[110,120]. Interestingly, expression of the catalytic subunit of the reverse transcriptase telomerase (TERT), which rescues the premature senescence of WS cells, reverts the limited growth phenotype of HGPS cells, although it is unclear whether this is mediated by a telomere-lengthening process or involves noncanonical functions of telomerase[121]. The link between telomere metabolism and lamin A is further emphasized by studies showing that lamin $\mathrm{A}$ is required for maintaining the proper spatial organization, chromatin structure, and length of telomeres[111,122]. The precise relationship between progeroid syndromes and telomere homeostasis, as well as the impact of altered WRN or lamin A function during normal aging, are works in progress. It is anticipated that these studies will provide mechanistic insights for the development of therapeutic agents for a wide range of age-associated diseases that impact distinct organs and tissues.

\section{ACKNOWLEDGMENTS}

We thank members of the Comai and Reddy labs for valuable discussions. The studies on WS and HGPS in our lab have been supported by the National Institutes of Health (R01AG023873), the Zumberge Innovation Fund, and the Progeria Research Foundation, and were conducted in a facility constructed with support from the Research Facilities Improvement Program Grant Number C06 RR014514-01, C06 RR10600-01, and C06 CA62528 from the National Center for Research Resources, National Institutes of Health. J.C. is supported by an NIH Predoctoral Fellowship (F31 GM076861).

\section{REFERENCES}

1. Epstein, C.J., Martin, G.M., Schultz, A.L., and Motulsky, A.G. (1966) Werner's syndrome. A review of its symptomatology, natural history, phatological features, genetics and relationship to the natural aging process. Medicine 45, 177-221.

2. Dyer, C. and Sinclair, A. (1998) The premature ageing syndromes: insights into the ageing process. Age Ageing 27, 73-80.

3. Goto, M. (1997) Hierarchical deterioration of body systems in Werner's syndrome: implications for normal aging. Mech. Aging Dev. 98, 239-254.

4. Y Yu, C.E., Oshima, J., Fu, Y.H., Wijsman, E.M., Hisama, F., Alisch, R., Matthews, S., Nakura, J., Miki, T., Ouais, S., Martin, G.M., Mulligan, J., and Schellenberg, G.D. (1996) Positional cloning of the Werner's syndrome gene. Science 272, 258-262.

5. Karow, J.K., Wu, L., and Hickson, I.D. (2000) RecQ family helicases: roles in cancer and aging. Curr. Opin. Genet. Dev. 10, 32-38.

6. Mohaghegh, P., Karow, J.K., Brosh, R.M., Jr., Bohr, V.A., and Hickson, I.D. (2001) The Bloom's and Werner's syndrome proteins are DNA structure-specific helicases. Nucleic Acids Res. 29, 2843-2849.

7. Shen, J.C. and Loeb, L.A. (2000) Werner syndrome exonuclease catalyzes structure-dependent degradation of DNA. Nucleic Acids Res. 28, 3260-3268.

8. Maizels, N. (2006) Dynamic roles for G4 DNA in the biology of eukaryotic cells. Nat. Struct. Mol. Biol. 13, 10551059.

9. Moser, M.J., Holley, W.R., Chatterjee, A., and Mian, I.S. (1997) The proofreading domain of Escherichia coli DNA poly merase I and other DNA and/or RNA exonuclease domains. Nucleic Acids Res. 25, 5110-5118.

10. Moser, M.J., Kamath-Loeb, A.S., Jacob, J.E., Bennett, S.E., Oshima, J., and Monnat, R.J., Jr. (2000) WRN helicase expression in Werner syndrome cell lines. Nucleic Acids Res. 28, 648-654. 
11. Fukuchi, K., Martin, G.M., and Monnat, R.J. (1989) Mutator phenotype of Werner syndrome is characterized by extensive deletions. Proc. Natl. Acad. Sci. U. S. A. 86, 5893-5897.

12. Gebhart, E., Bauer, R., Raub, U., Schinzel, M., Ruprecht, K.W., and Jonas, J.B. (1988) Spontaneous and induced chromosomal instability in Werner syndrome. Hum. Genet. 80, 135-139.

13. Salk, D., Au, K., Hoehn, H., and Martin, G.M. (1985) Cytogenetic aspects of Werner syndrome. Adv. Exp. Med. Biol. 190, 541-550.

14. Lebel, M. and Leder, P. (1998) A deletion within the murine Werner syndrome helicase induces sensitivity to inhibitors of topoisomerase and loss of cellular proliferative capacity. Proc. Natl. Acad. Sci. U. S. A. 95, 1309713102.

15. Lombard, D.B., Beard, C., Johnson, B., Marciniak, R.A., Dausman, J., Bronson, R., Buhlmann, J.E., Lipman, R., Curry, R., Sharpe, A., Jaenisch, R., and Guarente, L. (2000) Mutations in the WRN gene in mice accelerate mortality in a p53-null background. Mol. Cell. Biol. 20, 3286-3291.

16. Chang, S., Multani, A.S., Cabrera, N.G., Naylor, M.L., Laud, P., Lombard, D., Pathak, S., Guarente, L., and DePinho, R.A. (2004) Essential role of limiting telomeres in the pathogenesis of Werner syndrome. Nat. Genet. 36, 877-882.

17. Du, X., Shen, J., Kugan, N., Furth, E.E., Lombard, D.B., Cheung, C., Pak, S., Luo, G., Pignolo, R.J., DePinho, R.A., Guarente, L., and Johnson, F.B. (2004) Telomere shortening exposes functions for the mouse Werner and Bloom syndrome genes. Mol. Cell. Biol. 24, 8437-8446.

18. Li, B. and Comai, L. (2000) Functional interaction between $\mathrm{Ku}$ and the werner syndrome protein in DNA end processing. J. Biol. Chem. 275, 28349-28352.

19. Cooper, M.P., Machwe, A., Orren, D.K., Brosh, R.M., Ramsden, D., and Bohr, V.A. (2000) Ku complex interacts with and stimulates the Werner protein. Genes Dev. 14, 907-912.

20. Brosh, R.M., Jr., von Kobbe, C., Sommers, J.A., Karmakar, P., Opresko, P.L., Piotrowski, J., Dianova, I., Dianov, G.L., and Bohr, V.A. (2001) Werner syndrome protein interacts with human flap endonuclease 1 and stimulates its cleavage activity. EMBO J. 20, 5791-5801.

21. Brosh, R.M., Jr., Orren, D.K., Nehlin, J.O., Ravn, P.H., Kenny, M.K., Machwe, A., and Bohr, V.A. (1999) Functional and physical interaction between WRN helicase and human replication protein A. J. Biol. Chem. 274, 18341-18350. Spillare, E.A., Robles, A.I., Wang, X.W., Shen, J.C., Yu, C.E., Schellenberg, G.D., and Harris, C.C. (1999) p53mediated apoptosis is attenuated in Werner syndrome cells. Genes Dev. 13, 1355-1360. Kamath-Loeb, A.S., Johansson, E., Burgers, P.M., and Loeb, L.A. (2000) Functional interaction between the Werner Syndrome protein and DNA poly merase delta. Proc. Natl. Acad. Sci. U. S. A. 97, 4603-4608.

24. von Kobbe, C., Karmakar, P., Dawut, L., Opresko, P., Zeng, X., Brosh, R.M., Jr., Hickson, I.D., and Bohr, V.A. (2002) Colocalization, physical, and functional interaction between Werner and Bloom syndrome proteins. J. Biol. Chem. 277, 22035-22044.

25. Shen, J.C., Gray, M., Oshima, J., and Loeb, L. (1998) Characterization of Werner syndrome protein DNA helicase activity: directionality, substrate dependence and stimulation by replication protein A. Nucleic Acids Res. 26, 28792885.

26. Opresko, P.L., von Kobbe, C., Laine, J.P., Harrigan, J., Hickson, I.D., and Bohr, V.A. (2002) Telomere-binding protein TRF2 binds to and stimulates the Werner and Bloom syndrome helicases. J. Biol. Chem. 277, 41110-41119.

27. Opresko, P.L., Mason, P.A., Podell, E.R., Lei, M., Hickson, I.D., Cech, T.R., and Bohr, V.A. (2005) POT1 stimulates RecQ helicases WRN and BLM to unwind telomeric DNA substrates. J. Biol. Chem. 280, 32069-32080. Li, B., Navarro, S., Kasahara, N., and Comai, L. (2004) Identification and biochemical characterization of a Werner's syndrome protein complex with Ku70/80 and poly(ADP-ribose) polymerase-1. J. Biol. Chem. 279, 13659-13667. von Kobbe, C., Harrigan, J.A., Schreiber, V., Stiegler, P., Piotrowski, J., Dawut, L., and Bohr, V.A. (2004) Poly(ADP-ribose) polymerase 1 regulates both the exonuclease and helicase activities of the Werner syndrome protein. Nucleic Acids Res. 32, 4003-4014.

30. Baynton, K., Otterlei, M., Bjoras, M., von Kobbe, C., Bohr, V.A., and Seeberg, E. (2003) WRN interacts physically and functionally with the recombination mediator protein RAD52. J. Biol. Chem. 278, 36476-36486.

31. Otterlei, M., Bruheim, P., Ahn, B., Bussen, W., Karmakar, P., Baynton, K., and Bohr, V.A. (2006) Werner syndrome protein participates in a complex with RAD51, RAD54, RAD54B and ATR in response to ICL-induced replication arrest. J. Cell Sci. 119, 5137-5146.

32. Zhang, N., Kaur, R., Lu, X., Shen, X., Li, L., and Legerski, R.J. (2005) The Pso4 mRNA splicing and DNA repair complex interacts with WRN for processing of DNA interstrand cross-links. J. Biol. Chem. 280, 40559-40567.

33. Karmakar, P., Piotrowski, J., Brosh, R.M., Jr., Sommers, J.A., Miller, S.P., Cheng, W.H., Snowden, C.M., Ramsden, D.A., and Bohr, V.A. (2002) Werner protein is a target of DNA-dependent protein kinase in vivo and in vitro, and its cataly tic activities are regulated by phosphory lation. J. Biol. Chem 277, 18291-18302.

34. Karmakar, P., Snowden, C.M., Ramsden, D.A., and Bohr, V.A. (2002) Ku heterodimer binds to both ends of the Werner protein and functional interaction occurs at the Werner N-terminus. Nucleic Acids Res. 30, 3583-3591.

35. Li, B. and Comai, L. (2001) Requirements for the nucleolytic processing of DNA ends by the Werner syndrome protein-Ku70/80 complex. J. Biol. Chem 276, 9896-9902.

36. Li, B. and Comai, L. (2002) Displacement of DNA-PKcs from DNA ends by the Werner syndrome protein. Nucleic Acids Res. 30, 3653-3661. 
37. Orren, D.K., Machwe, A., Karmakar, P., Piotrowski, J., Cooper, M.P., and Bohr, V.A. (2001) A functional interaction of Ku with Werner exonu clease facilitates digestion of damaged DNA. Nucleic Acids Res. 29, 1926-1934.

38. Downs, J.A. and Jackson, S.P. (2004) A means to a DNA end: the many roles of Ku. Nat. Rev. Mol. Cell Biol. 5, 367378.

39. Fisher, T.S. and Zakian, V.A. (2005) Ku: a multifunctional protein involved in telomere maintenance. DNA Repair (Amst.) 4, 1215-1226.

40. DiFilippantonio, M.J., Zhu, J., Chen, H.T., Meffre, E., Nussenzweig, M.C., Max, E.E., Ried, T., and Nussenzweig, A. (2000) DNA repair protein Ku80 suppresses chromosomal aberrations and malignant transformation. Nature 404, $510-514$.

41. Vogel, H., Lim, D.S., Karsenty, G., Finegold, M., and Hasty, P. (1999) Deletion of Ku86 causes early onset of senescence in mice. Proc. Natl. Acad. Sci. U. S. A. 96, 10770-10775.

42. Ferguson, D.O., Sekiguchi, J.M., Chang, S., Frank, K.M., Gao, Y., DePinho, R.A., and Alt, F.W. (2000) The nonhomologous end-joining pathway of DNA repair is required for genomic stability and the suppression of translocations. Proc. Natl. Acad. Sci. U. S. A. 97, 6630-6633.

43. Li, H., Vogel, H., Holcomb, V.B., Gu, Y., and Hasty, P. (2007) Deletion of Ku70, Ku80, or both causes early aging without substantially increased cancer. Mol. Cell. Biol. 27, 8205-8214.

44. Crabbe, L., Verdun, R.E., Haggblom, C.I., and Karlseder, J. (2004) Defective telomere lagging strand synthesis in cells lacking WRN helicase activity. Science 306, 1951-1953.

45. Opresko, P.L., Otterlei, M., Graakjaer, J., Bruheim, P., Dawut, L., Kolvraa, S., May, A., Seidman, M.M., and Bohr, V.A. (2004) The Werner syndrome helicase and exonuclease cooperate to resolve telomeric D loops in a manner regulated by TRF1 and TRF2. Mol. Cell 14, 763-774.

46. Machwe, A., Xiao, L., and Orren, D.K. (2004) TRF2 recruits the Werner syndrome (WRN) exonuclease for processing of telomeric DNA. Oncogene 23, 149-156.

47. Li, B., Reddy, S., and Comai, L. (2009) Sequence-specific processing of telomeric 3' overhangs by the Werner syndrome protein exonuclease activity. Aging 1, 289-302.

48.

Laud, P.R., Multani, A.S., Bailey, S.M., Wu, L., Ma, J., Kingsley, C., Lebel, M., Pathak, S., DePinho, R.A., and Chang, S. (2005) Elevated telomere-telomere recombination in WRN-deficient, telomere dy sfunctional cells promotes escape from senescence and en gagement of the ALT pathway. Genes Dev. 19, 2560-2570.

49. Griffith, J.D., Comeau, L., Rosenfield, S., Stansel, R.M., Bianchi, A., Moss, H., and de Lange, T. (1999) Mammalian telomeres end in a large duplex loop. Cell 97, 503-514.

50. Nikitina, T. and Woodcock, C.L. (2004) Closed chromatin loops at the ends of chromosomes. J. Cell Biol. 166, 161165.

51. Murti, K.G. and Prescott, D.M. (1999) Telomeres of polytene chromosomes in a ciliated protozoan terminate in duplex DNA loops. Proc. Natl. Acad. Sci. U. S. A. 96, 14436-14439.

52. Karlseder, J., Broccoli, D., Dai, Y., Hardy, S., and de Lange, T. (1999) p53-and ATM-dependent apoptosis induced by telomeres lacking TRF2. Science 283, 1321-1325.

53. Karlseder, J., Smogorzewska, A., and de Lange, T. (2002) Senescence induced by altered telomere state, not telomere loss. Science 295, 2446-2449.

54. d'Adda di Fagagna, F., Teo, S.H., and Jackson, S.P. (2004) Functional links between telomeres and proteins of the DNA-damage response. Genes Dev. 18, 1781-1799.

55. Ferreira, M.G., Miller, K.M., and Cooper, J.P. (2004) Indecent exposure: when telomeres become uncapped. Mol. Cell 13, 7-18.

56. de Lange, T. (2005) Shelterin: the protein complex that shapes and safeguards human telomeres. Genes Dev. 19, 2100-2110.

57. Wang, R.C., Smogorzewska, A., and de Lange, T. (2004) Homologous recombination generates T-loop-sized deletions at human telomeres. Cell 119, 355-368.

58. Li, B., Jog, S.P., Reddy, S., and Comai, L. (2008) WRN controls formation of extrachromosomal telomeric circles and is required for TRF2DeltaB-mediated telomere shortening. Mol. Cell. Biol. 28, 1892-1904.

59. Gaubatz, J.W. (1990) Extrachromosomal circular DNAs and genomic sequence plasticity in eukaryotic cells. Mutat. Res. 237, 271-292.

60. Cohen, S., Regev, A., and Lavi, S. (1997) Small polydispersed circular DNA (spcDNA) in human cells: association with genomic instability. Oncogene 14, 977-985.

61. Kunisada, T., Yamagishi, H., Ogita, Z., Kirakawa, T., and Mitsui, Y. (1985) Appearance of extrachromosomal circular DNAs during in vivo and in vitro ageing of mammalian cells. Mech. Ageing Dev. 29, 89-99.

62. Sinclair, D.A. and Guarente, L. (1997) Extrachromosomal rDNA circles--a cause of aging in yeast. Cell 91, 10331042.

63. Compton, S.A., Choi, J.H., Cesare, A.J., Ozgur, S., and Griffith, J.D. (2007) Xrcc3 and Nbs1 are required for the production of extrachromosomal telomeric circles in human alternative len gthening of telomere cells. Cancer Res. 67, 1513-1519.

64. Wu, L., Multani, A.S., He, H., Cosme-Blanco, W., Deng, Y., Deng, J.M., Bachilo, O., Pathak, S., Tahara, H., Bailey, S.M., Deng, Y., Behringer, R.R., and Chang, S. (2006) Pot 1 deficiency initiates DNA damage checkpoint activation and aberrant homologous recombination at telomeres. Cell 126, 49-62. 
65. Stellwagen, A.E., Haimberger, Z.W., Veatch, J.R., and Gottschling, D.E. (2003) Ku interacts with telomerase RNA to promote telomere addition at native and broken chromosome ends. Genes Dev. 17, 2384-2395.

66. Ting, N.S., Yu, Y., Pohorelic, B., Lees-Miller, S.P., and Beattie, T.L. (2005) Human Ku70/80 interacts directly with hTR, the RNA component of human telomerase. Nucleic Acids Res. 33, 2090-2098.

67. Fisher, T.S., Taggart, A.K., and Zakian, V.A. (2004) Cell cycle-dependent regulation of yeast telomerase by Ku. Nat. Struct. Mol. Biol. 11, 1198-1205.

68. Riha, K., Watson, J.M., Parkey, J., and Shippen, D.E. (2002) Telomere length deregulation and enhanced sensitivity to genotoxic stress in Arabidopsis mutants deficient in Ku70. EMBO J. 21, 2819-2826.

69. Polotnianka, R.M., Li, J., and Lustig, A.J. (1998) The yeast Ku heterodimer is essential for protection of the telomere against nucleolytic and recombinational activities. Curr. Biol. 8, 831-834.

70. Li, B., Conway, N., Navarro, S., Comai, L., and Comai, L. (2005) A conserved and species-specific functional interaction between the Werner syndrome-like exonuclease atWEX and the Ku heterodimer in Arabidopsis. Nucleic Acids Res. 33, 6861-6867.

71. Zellinger, B., Akimcheva, S., Puizina, J., Schirato, M., and Riha, K. (2007) Ku suppresses formation of telomeric circles and alternative telomere lengthening in Arabidopsis. Mol. Cell 27, 163-169.

72. Ackerman, J. and Gilbert-Barness, E. (2002) Hutchinson-Gilford progeria syndrome: a pathologic study. Pediatr. Pathol. Mol. Med. 21, 1-13.

73. Pollex, R.L. and Hegele, R.A. (2004) Hutchinson-Gilford progeria syndrome. Clin. Genet. 66, 375-381.

74. Hennekam, R.C. (2006) Hutchinson-Gilford progeria syndrome: review of the phenotype. Am. J. Med. Genet. A 140, 2603-2624.

75. Eriksson, M., Brown, W.T., Gordon, L.B., Glynn, M.W., Singer, J., Scott, L., Erdos, M.R., Robbins, C.M., Moses, T.Y., Berglund, P., Dutra, A., Pak, E., Durkin, S., Csoka, A.B., Boehnke, M., Glover, T.W., and Collins, F.S. (2003) Recurrent de novo point mutations in lamin A cause Hutchinson-Gilford progeria syndrome. Nature 423, $293-298$.

76. De Sandre-Giovannoli, A., Bernard, R., Cau, P., Navarro, C., Amiel, J., Boccaccio, I., Lyonnet, S., Stewart, C.L., Munnich, A., Le Merrer, M., and Levy, N. (2003) Lamin a truncation in Hutchinson-Gilford progeria. Science 300, 2055.

77. Beck, L.A., Hosick, T.J., and Sinensky, M. (1990) Isoprenylation is required for the processing of the lamin A precursor. J. Cell Biol. 110, 1489-1499.

78. Lutz, R.J., Trujillo, M.A., Denham, K.S., Wenger, L., and Sinensky, M. (1992) Nucleoplasmic localization of prelamin A: implications for prenylation-dependent lamin A assembly into the nuclear lamina. Proc. Natl. Acad. Sci. U. S. A. 89, 3000-3004.

79. Capell, B.C., Erdos, M.R., Madigan, J.P., Fiordalisi, J.J., Varga, R., Conneely, K.N., Gordon, L.B., Der, C.J., Cox, A.D., and Collins, F.S. (2005) Inhibiting farnesylation of progerin prevents the characteristic nuclear blebbing of Hutchinson-Gilford progeria syndrome. Proc. Natl. Acad. Sci. U. S. A. 102, 12879-12884.

80. Glynn, M.W. and Glover, T.W. (2005) Incomplete processing of mutant lamin A in Hutchinson-Gilford progeria leads to nuclear abnormalities, which are reversed by farnesyltransferase inhibition. Hum. Mol. Genet. 14, 29592969.

81. Mallampalli, M.P., Huyer, G., Bendale, P., Gelb, M.H., and Michaelis, S. (2005) Inhibiting farnesylation reverses the nuclear morphology defect in a HeLa cell model for Hutchinson-Gilford progeria syndrome. Proc. Natl. Acad. Sci. U. S. A. 102, 14416-14421.

82. Toth, J.I., Yang, S.H., Qiao, X., Beigneux, A.P., Gelb, M.H., Moulson, C.L., Miner, J.H., Young, S.G., and Fong, L.G. (2005) Blocking protein farnesyltransferase improves nuclear shape in fibroblasts from humans with progeroid syndromes. Proc. Natl. Acad. Sci. U. S. A. 102, 12873-12878.

83. Candelario, J., Sudhakar, S., Navarro, S., Reddy, S., and Comai, L. (2008) Perturbation of wild-type lamin A metabolism results in a progeroid phenotype. Aging Cell 7, 355-367.

84. Broers, J.L., Hutchison, C.J., and Ramaekers, F.C. (2004) Laminopathies. J. Pathol. 204, 478-488.

85. Mounkes, L., Kozlov, S., Burke, B., and Stewart, C.L. (2003) The laminopathies: nuclear structure meets disease. Curr. Opin. Genet. Dev. 13, 223-230.

86. Worman, H.J. and Bonne, G. (2007) "Laminopathies": a wide spectrum of human diseases. Exp. Cell Res. 313, 21212133 .

87. Goldman, R.D., Gruenbaum, Y., Moir, R.D., Shumaker, D.K., and Spann, T.P. (2002) Nuclear lamins: building blocks of nuclear architecture. Genes Dev. 16, 533-547.

88. Holmer, L. and Worman, H.J. (2001) Inner nuclear membrane proteins: functions and targeting. Cell. Mol. Life Sci. 58, 1741-1747.

89. Han, X., Feng, X., Rattner, J.B., Smith, H., Bose, P., Suzuki, K., Soliman, M.A., Scott, M.S., Burke, B.E., and Riabowol, K. (2008) Tethering by lamin A stabilizes and targets the ING1 tumour suppressor. Nat. Cell Biol. 10, 1333-1340.

90. Shimi, T., Pfleghaar, K., Kojima, S., Pack, C.G., Solovei, I., Goldman, A.E., Adam, S.A., Shumaker, D.K., Kinjo, M., Cremer, T., and Goldman, R.D. (2008) The A- and B-type nuclear lamin networks: microdomains involved in chromatin organization and transcription. Genes Dev. 22, 3409-3421.

91. Zastrow, M.S., Vlcek, S., and Wilson, K.L. (2004) Proteins that bind A-type lamins: integrating isolated clues. J. Cell Sci. 117, 979-987. 
92. Broers, J.L., Ramaekers, F.C., Bonne, G., Yaou, R.B., and Hutchison, C.J. (2006) Nuclear lamins: laminopathies and their role in premature ageing. Physiol. Rev. 86, 967-1008.

93. Ivorra, C., Kubicek, M., Gonzalez, J.M., Sanz-Gonzalez, S.M., Alvarez-Barrientos, A., O'Connor, J.E., Burke, B., and Andres, V. (2006) A mechanism of AP-1 suppression through interaction of c-Fos with lamin A/C. Genes Dev. 20, 307-320.

94. Goldman, R.D., Shumaker, D.K., Erdos, M.R., Eriksson, M., Goldman, A.E., Gordon, L.B., Gruenbaum, Y., Khuon, S., Mendez, M., Varga, R., and Collins, F.S. (2004) Accumulation of mutant lamin A causes progressive changes in nuclear architecture in Hutchinson-Gilford progeria syndrome. Proc. Natl. Acad. Sci. U. S. A. 101, 8963-8968.

95. Scaffidi, P. and Misteli, T. (2005) Reversal of the cellular phenotype in the premature aging disease HutchinsonGilford progeria syndrome. Nat. Med. 11, 718-719.

96. Dahl, K.N., Scaffidi, P., Islam, M.F., Yodh, A.G., Wilson, K.L., and Misteli, T. (2006) Distinct structural and mechanical properties of the nuclear lamina in Hutchinson-Gilford progeria syndrome. Proc. Natl. Acad. Sci. U.S. A. 103, 10271-10276.

97. Columbaro, M., Capanni, C., Mattioli, E., Novelli, G., Parnaik, V.K., Squarzoni, S., Maraldi, N.M., and Lattanzi, G. (2005) Rescue of heterochromatin organization in Hutchinson-Gilford progeria by drug treatment. Cell. Mol. Life Sci. 314, 453-562.

98. Shumaker, D.K., Dechat, T., Kohlmaier, A., Adam, S.A., Bozovsky, M.R., Erdos, M.R., Eriksson, M., Goldman, A.E., Khuon, S., Collins, F.S., Jenuwein, T., and Goldman, R.D. (2006) Mutant nuclear lamin A leads to progressive alterations of epigenetic control in premature aging. Proc. Natl. Acad. Sci. U. S. A. 103, 8703-8708.

99. Spann, T.P., Goldman, A.E., Wang, C., Huang, S., and Goldman, R.D. (2002) Alteration of nuclear lamin organization inhibits RNA poly merase II-dependent transcription. J. Cell Biol. 156, 603-608.

100. Park, W.Y., Hwang, C.I., Kang, M.J., Seo, J.Y., Chung, J.H., Kim, Y.S., Lee, J.H., Kim, H., Kim, K.A., Yoo, H.J., and Seo, J.S. (2001) Gene profile of replicative senescence is different from progeria or elderly donor. Biochem. Biophys. Res. Commun. 282, 934-939.

101. Csoka, A.B., English, S.B., Simkevich, C.P., Ginzinger, D.G., Butte, A.J., Schatten, G.P., Rothman, F.G., and Sedivy, J.M. (2004) Genome-scale expression profiling of Hutchinson-Gilford progeria syndrome reveals widespread transcriptional misregu lation leading to mesodermal/mesenchy mal defects and accelerated atherosclerosis. Aging Cell 3, 235-243.

102. Scaffidi, P. and Misteli, T. (2008) Lamin A-dependent misregulation of adult stem cells associated with accelerated ageing. Nat. Cell Biol. 10, 452-459.

103. Shumaker, D.K., Solimando, L., Sengupta, K., Shimi, T., Adam, S.A., Grunwald, A., Strelkov, S.V., Aebi, U., Cardoso, M.C., and Goldman, R.D. (2008) The highly conserved nuclear lamin Ig-fold binds to PCNA: its role in DNA replication. J. Cell Biol. 181, 269-280.

104. Kennedy, B.K., Barbie, D.A., Classon, M., Dyson, N., and Harlow, E. (2000) Nuclear organization of DNA replication in primary mammalian cells. Genes Dev. 14, 2855-2868.

105. Moir, R.D., Yoon, M., Khuon, S., and Goldman, R.D. (2000) Nuclear lamins A and B1: different pathways of assembly during nuclear envelope formation in living cells. J. Cell Biol. 151, 1155-1168.

106. Liu, B., Wang, J., Chan, K.M., Tjia, W.M., Deng, W., Guan, X., Huang, J.D., Li, K.M., Chau, P.Y., Chen, D.J., Pei, D., Pendas, A.M., Cadinanos, J., Lopez-Otin, C., Tse, H.F., Hutchison, C., Chen, J., Cao, Y., Cheah, K.S., Try ggvason, K., and Zhou, Z. (2005) Genomic instability in laminopathy -based premature aging. Nat. Med. 11, 780785.

107. McClintock, D., Ratner, D., Lokuge, M., Owens, D.M., Gordon, L.B., Collins, F.S., and Djabali, K. (2007) The mutant form of lamin A that causes Hutchinson-Gilford progeria is a biomarker of cellular aging in human skin. PLoS One 2, e1269.

108. Scaffidi, P. and Misteli, T. (2006) Lamin A-dependent nuclear defects in human aging. Science 312, $1059-1063$.

109. Cao, K., Capell, B.C., Erdos, M.R., Djabali, K., and Collins, F.S. (2007) A lamin A protein isoform overexpressed in Hutchinson-Gilford progeria syndrome interferes with mitosis in progeria and normal cells. Proc. Natl. Acad. Sci. U. S. A. 104, 4949-4954.

110. Huang, S., Risques, R.A., Martin, G.M., Rabinovitch, P.S., and Oshima, J. (2008) Accelerated telomere shortening and replicative senescence in human fibroblasts overexpressing mutant and wild-type lamin A. Exp. Cell Res. 314, 82-91.

111. Raz, V., Vermolen, B.J., Garini, Y., Onderwater, J.J., Mommaas-Kienhuis, M.A., Koster, A.J., Young, I.T., Tanke, H., and Dirks, R.W. (2008) The nuclear lamin a promotes telomere aggregation and centromere peripheral localization during sen escence of human mesenchymal stem cells. J. Cell Sci. 121, 4018-4028.

112. Sullivan, T., Escalante-Alcalde, D., Bhatt, H., Anver, M., Bhat, N., Nagashima, K., Stewart, C.L., and Burke, B. (1999) Loss of A-type lamin expression compromises nuclear envelope integrity leading to muscular dystrophy. $J$. Cell Biol. 147, 913-920.

113. Mounkes, L.C., Kozlov, S., Hernandez, L., Sullivan, T., and Stewart, C.L. (2003) A progeroid syndrome in mice is caused by defects in A-type lamins. Nature 423, 298-301. 
114. Varga, R., Eriksson, M., Erdos, M.R., Olive, M., Harten, I., Kolodgie, F., Capell, B.C., Cheng, J., Faddah, D., Perkins, S., Avallone, H., San, H., Qu, X., Ganesh, S., Gordon, L.B., Virmani, R., Wight, T.N., Nabel, E.G., and Collins, F.S. (2006) Progressive vascular smooth muscle cell defects in a mouse model of Hutchinson-Gilford progeria syndrome. Proc. Natl. Acad. Sci. U. S. A.103, 3250-3255.

115. Yang, S.H., Bergo, M.O., Toth, J.I., Qiao, X., Hu, Y., Sandoval, S., Meta, M., Bendale, P., Gelb, M.H., Young, S.G., and Fong, L.G. (2005) Blocking protein farnesyltransferase improves nuclear blebbing in mouse fibroblasts with a targeted Hutchinson-Gilford progeria syndrome mutation. Proc. Natl. Acad. Sci. U. S. A. 102, 10291-10296.

116. Yang, S.H., Qiao, X., Farber, E., Chang, S.Y., Fong, L.G., and Young, S.G. (2008) Eliminating the synthesis of mature lamin A reduces disease phenotypes in mice carrying a Hutchinson-Gilford progeria syndrome allele. J. Biol. Chem. 283, 7094-7099.

117. Bergo, M.O., Gavino, B., Ross, J., Schmidt, W.K., Hong, C., Kendall, L.V., Mohr, A., Meta, M., Genant, H., Jiang, Y., Wisner, E.R., Van Bruggen, N., Carano, R.A., Michaelis, S., Griffey, S.M., and Young, S.G. (2002) Zmpste24 deficiency in mice causes spontaneous bone fractures, muscle weakness, and a prelamin A processing defect. Proc. Natl. Acad. Sci. U. S. A. 99, 13049-13054.

118. Pendas, A.M., Zhou, Z., Cadinanos, J., Freije, J.M., Wang, J., Hultenby, K., Astudillo, A., Wernerson, A., Rodriguez, F., Tryggvason, K., and Lopez-Otin, C. (2002) Defective prelamin A processing and muscular and adipocyte alterations in Zmpste24 metalloproteinase-deficient mice. Nat. Genet. 31, 94-99.

119. Agarwal, A.K., Fryns, J.P., Auchus, R.J., and Garg, A. (2003) Zinc metalloproteinase, ZMPSTE24, is mutated in mandibuloacral dy splasia. Hum. Mol. Genet. 12, 1995-2001.

120. Decker, M.L., Chavez, E., Vulto, I., and Lansdorp, P.M. (2009) Telomere length in Hutchinson-Gilford progeria syndrome. Mech. Ageing Dev. 130, 377-383.

121. Kudlow, B.A., Stanfel, M.N., Burtner, C.R., Johnston, E.D., and Kennedy, B.K. (2008) Suppression of proliferative defects associated with processing-defective lamin a mutants by hTERT or inactivation of p53. Mol. Biol. Cell 19, $5238-5248$.

122. Gonzalez-Suarez, I., Redwood, A.B., Perkins, S.M., Vermolen, B., Lichtensztejin, D., Grotsky, D.A., MorgadoPalacin, L., Gapud, E.J., Sleckman, B.P., Sullivan, T., Sage, J., Stewart, C.L., Mai, S., and Gonzalo, S. (2009) Novel roles for A-type lamins in telomere biology and the DNA damage response pathway. EMBO J. 28(16), 2414-2427.

123. Wang, Y., Ghosh, G., and Hendrickson, E.A. (2009) Ku86 represses lethal telomere deletion events in human somatic cells. Proc. Natl. Acad. Sci. U. S. A. 106, 12430-12435.

\section{This article should be cited as follows:}

Li, B., Jog, S., Candelario, J., Reddy, S., and Comai, L. (2009) Altered nuclear functions in progeroid syndromes: a paradigm for aging research. TheScientificWorldJOURNAL 9, 1449-1462. DOI 10.1100/tsw.2009.159. 

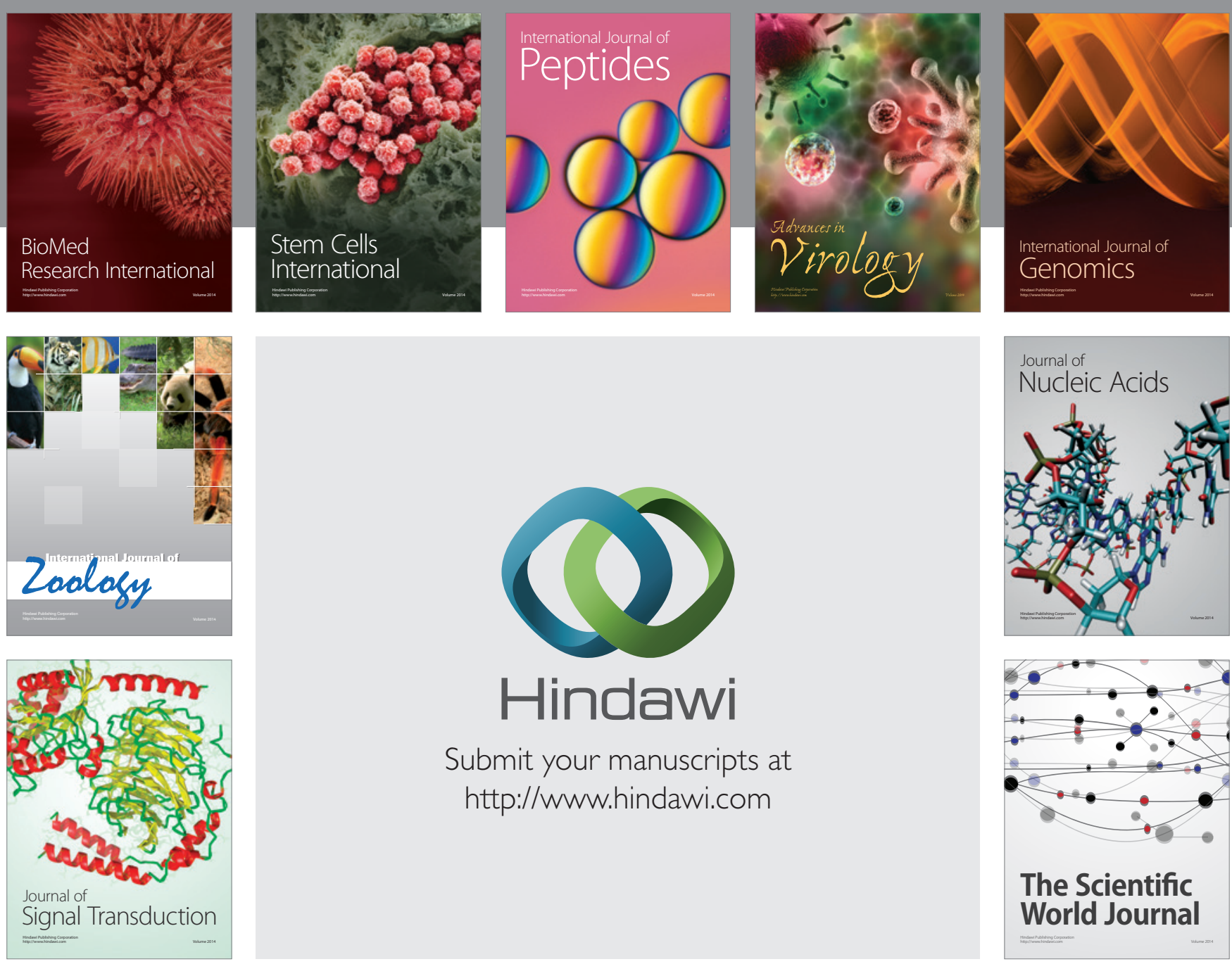

Submit your manuscripts at

http://www.hindawi.com
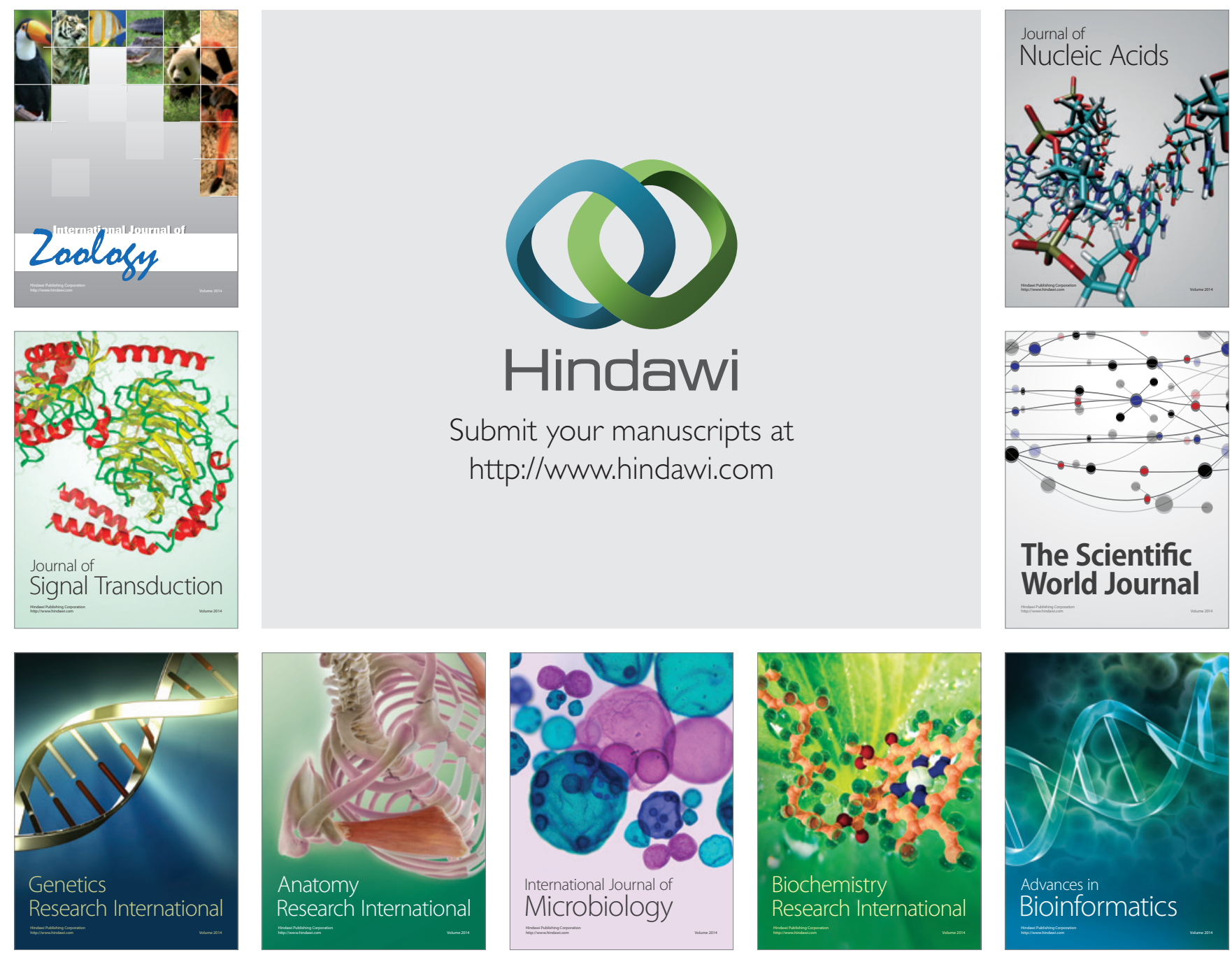

The Scientific World Journal
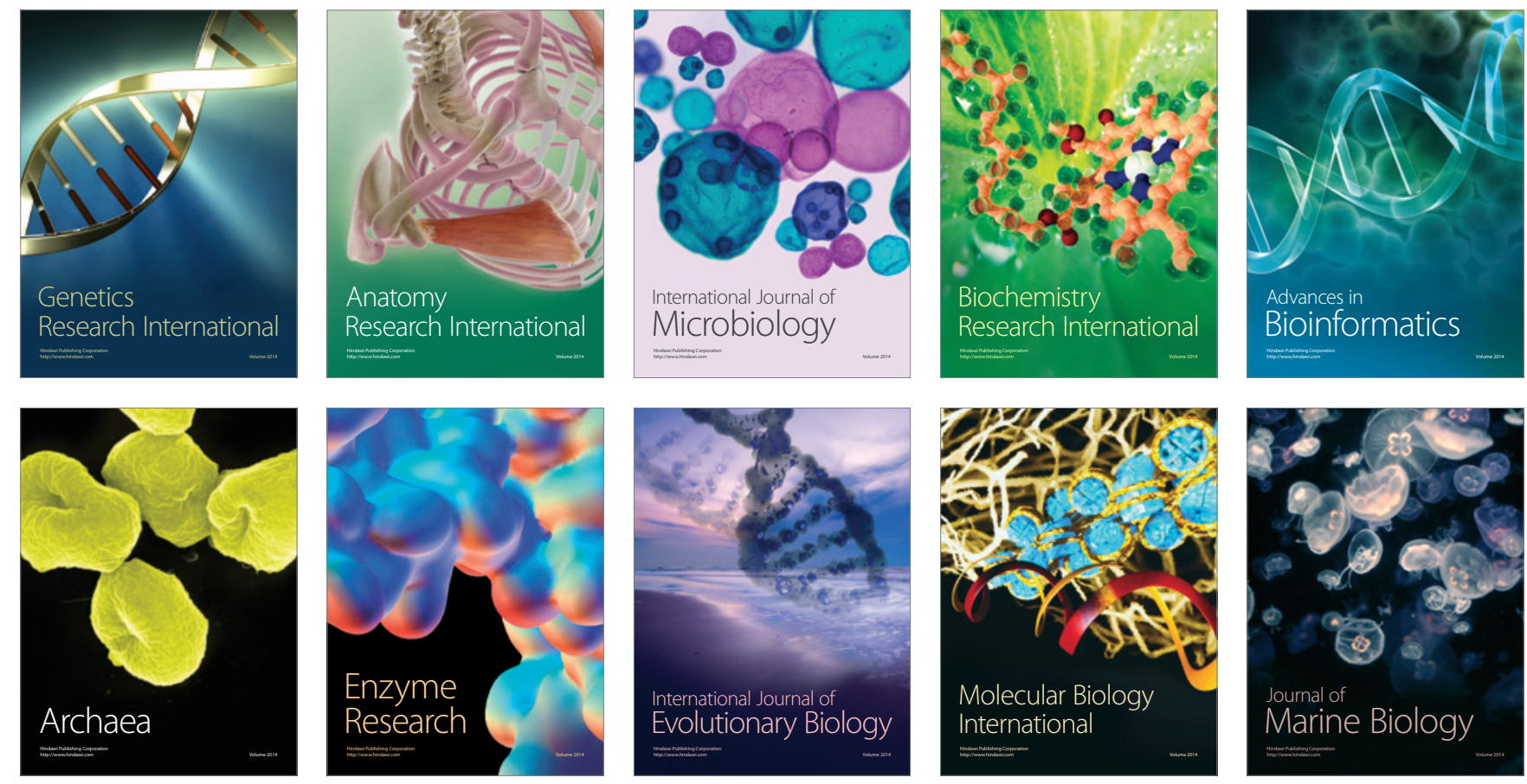